\title{
ASSOCIATION BETWEEN EXPOSURE TO ENVIRONMENTAL TOBACCO SMOKE AND THE RISK OF UNCONTROLLED ASTHMA IN CHILDREN
}

\author{
Sutaryono ${ }^{1)}$, Hartono ${ }^{2)}$, Probandari NA²), Setyono P3), \\ Budiastuti S3), Masykuri M4) \\ 1)School of Health Sciences Muhammadiyah, Klaten \\ 2)Faculty of Medicine, Sebelas Maret University \\ 3)Study Program in Environmental Science, Sebelas Maret University \\ 4)Study Progeam in Biosciences, Sebelas Maret University
}

\begin{abstract}
Background: Studies have shown that exposure of environmental tobacco smoke (ETS) is harmful to infant and child health. Cigarette smoke contains nicotine that may cause inflammation and airway obstruction resulting in uncontrolled asthma. Therefore, efforts to control tobacco are needed in society. The study aimed to determine the association between exposure to environmental tobacco smoke and the risk of uncontrolled asthma in children.
\end{abstract}

Subjects and Method: This was an analytic observational study with crosssectional design. The study was carried out at three hospitals: Center for Healthy Lung Community (BBKPM), Surakarta, Dr. Moewardi Hospital, Surakarta, and Lung Health Center, Klaten, Central Java. A sample of 114 children aged 12-18 years old, diagnosed as having asthma based on medical record from January 2016 to March 2017 from the three hospitals, were selected for this study. The dependent variable was asthma control. The independent variable was environmental tobacco smoke exposure. Asthma control was assessed by Asthma Control Test (ACT), with a score less than 20 classified as uncontrolled asthma and a score greater or equal to 20 classified as controlled asthma. The data on ETS were collected by questionnaire. The data were analyzed usig Odds Ratio and Chi Square test.

Results: The asthmatic children under study had mean age $=15$ years. Male $=$ 47.4\%. Female $=52.6 \%$. Exposure to ETS was associated with an increased risk of uncontrolled asthma in asthmatic children $(\mathrm{OR}=3.20 ; 95 \% \mathrm{CI}=1.40$ to 6.90; $\mathrm{p}=0.003$ ).

Conclusion: Children who are exposed to environmental tobacco smoke (ETS) have a higher risk of uncontrolled asthma. Therefore, a free-smoking area is needed for children with asthma.

Keywords: asthma, environmental tobacco smoke, uncontrolled asthma

Correspondence: Sutaryono. Sekolah Tinggi Ilmu Kesehatan

Muhammadiyah, Klaten. Email : sutar.on@gmail.com 